\title{
Bioengineered Tissues for Urogenital Repair in Children
}

\author{
ANTHONY ATALA \\ Institute For Regenerative Medicine and Department of Urology, Wake Forest University School of Medicine, \\ Winston-Salem, North Carolina 27157
}

\begin{abstract}
The most common congenital abnormalities involve the genitourinary system. These include hypospadias, in which the urethral opening develops in an improper position, and bladder exstrophy, in which the bladder develops on the outer surface of the abdomen. Children with these conditions will require immediate and multiple reconstructive surgeries. Currently, reconstruction may be performed with native nonurologic tissues (skin, gastrointestinal segments, or mucosa), homologous tissues from a donor (cadaver or living donor kidney), heterologous tissues or substances (bovine collagen), or artificial materials (silicone, polyurethane, teflon). However, these materials often lead to complications after reconstruction, either because the implanted tissue is rejected, or because inherently different functional parameters cause a mismatch in the system. For example, replacement of bladder tissue with gastrointestinal segments can be problematic due to the opposite ways in which these two tissues handle solutes-urologic tissue normally excretes material, and gastrointestinal tissue generally absorbs the same materials. This mismatched state can lead to metabolic complications as well as infection and other issues. The replacement of lost or deficient urologic tissues with functionally equivalent ones would improve the outcome of reconstructive surgery in the genitourinary system. This goal may soon be attainable with the use of tissue engineering techniques. (Pediatr Res 63: 569-575, 2008)
\end{abstract}

\section{TISSUE ENGINEERING STRATEGIES FOR UROGENITAL REPAIR}

$\mathrm{T}$ issue engineering uses the principles of cell transplantation, materials science, and biomedical engineering to develop biologic substitutes that can restore and maintain normal function of damaged or lost tissues and organs. It can involve injection of functional cells into a nonfunctional site to stimulate regeneration, or it may involve the use of natural or synthetic matrices, often termed scaffolds, which encourage the body's natural ability to repair itself and assist in determination of the orientation and direction of new tissue growth. Often, tissue engineering uses a combination of both of these techniques. For example, matrices seeded with cells can be implanted into the body to encourage the growth or regeneration of functional tissue.

Received November 15, 2007; accepted November 29, 2007.

Correspondence: Anthony Atala, M.D., Wake Forest University School of Medicine, Medical Center Blvd., Winston Salem, NC 27157; e-mail: aatala@wfubmc.edu.

DOI: 10.1203/PDR.0b013e3181660639

\section{The Use of Cells in Urogenital Tissue Engineering Applications}

Often, when cells are used for tissue engineering, donor tissue is removed and dissociated into individual cells, which are implanted directly into the host or expanded in culture, attached to a support matrix, and then implanted. The implanted tissue can be heterologous, allogeneic, or autologous. Ideally, this approach allows lost tissue function to be restored or replaced in toto with limited complications (1-6).

Autologous cells are the ideal choice, as their use circumvents many of the inflammatory and rejection issues associated with a nonself donor. However, a major concern has been that, in cases where cells must be expanded from a particular organ, there may not be enough normal cells present in the diseased organ to begin the process. Recent research suggests that this may not be the case, however. For example, one study has shown that cultured neuropathic bladder smooth muscle cells possess and maintain different characteristics than normal smooth muscle cells in vitro, as demonstrated by growth assays, contractility and adherence tests in vitro (7). Despite these differences, when neuropathic smooth muscle cells were cultured in vitro, and then seeded onto matrices and implanted in vivo, the tissue engineered constructs showed the same properties as the constructs engineered with normal cells (8). It is now known that genetically normal progenitor cells, which are the reservoirs for new cell formation, are present even in diseased tissue. These normal progenitors are programmed to give rise to normal tissue, regardless of whether they reside in a normal or diseased environment. Therefore, the stem cell niche and its role in normal tissue regeneration remains a fertile area of ongoing investigation.

Stem cells. Most current strategies for tissue engineering depend upon a sample of autologous cells from the diseased organ of the host. In some instances, primary autologous human cells cannot be expanded from a particular organ, such as the pancreas. In these situations, pluripotent human stem cells are envisioned to be an ideal source of cells, as they can differentiate into nearly any replacement tissue in the body.

Embryonic stem cells exhibit two remarkable properties: the ability to proliferate in an undifferentiated, but still pluripotent state (self-renewal), and the ability to differentiate into a large number of specialized cell types (9). They can be isolated from the inner cell mass of the embryo during the blastocyst stage, which occurs 5 days postfertilization. These

Abbreviations: PGA, polyglycolic acid; SIS, small intestine submucosa 
cells have been maintained in the undifferentiated state for at least 80 passages when grown using current published protocols (10). In addition, many protocols for differentiation into specific cell types in culture have been published. However, many uses of these cells are currently banned in the United States due to the ethical dilemmas that are associated with the manipulation of embryos in culture.

Adult stem cells have the advantage of avoiding some of the ethical issues associated with embryonic cells, and, unlike embryonic cells, they do not transdifferentiate into a malignant phenotype, so there is a diminished risk of teratoma formation should the cells be implanted in vivo. However, adult stem cells are limited for clinical use because expansion to the large quantities needed for tissue engineering is difficult.

Fetal stem cells derived from amniotic fluid and placentas have recently been described and represent a novel source of stem cells $(11,12)$. The cells express markers consistent with human embryonic stem cells, such as octamer-4 and stagespecific embryonic antigen-4, but they do not form teratomas. The cells are multipotent and are able to differentiate into cells from all three germ layers. In addition, the cells have a high replicative potential and could be stored for future use, without the risks of rejection and without ethical concerns.

Further, the process of therapeutic cloning can be used to generate stem cell lines. In this process, embryos are created by inserting the nuclear material of a donor somatic cell into an enucleated oocyte, and the resulting blastocyst is explanted in culture. The inner cell mass of these embryos contains embryonic stem cells that are genetically identical to the source. These stem cells are autologous to the donor, and they have the potential to become almost any type of cell in the adult body. Stem cells derived from therapeutic cloning applications would be useful in tissue and organ replacement applications (13). A particularly useful application for these cells would be in the treatment of end-stage kidney disease, for which there is limited availability of immunocompatible tissue transplants.

\section{Biomaterials for Genitourinary Tissue Construction}

Biomaterials in genitourinary tissue engineering function as an artificial extracellular matrix (ECM) and are used to replace biologic and mechanical functions of native ECM found in tissues in the body. Biomaterials facilitate the localization and delivery of cells, or bioactive factors (e.g., cell adhesion peptides, growth factors), to desired sites in the body, as well as define a three-dimensional space for the formation of new tissues with appropriate structure. They also serve as a guide for the development of new tissues with appropriate function $(14,15)$. Direct injection of cell suspensions without such matrices has been used in some cases, but without this scaffold function, it is difficult to control the localization of transplanted cells $(16,17)$.

The ideal biomaterial should be biocompatible, promote cellular interaction and tissue development, and possess the proper mechanical and physical properties found in the tissue to be generated. Generally, three classes of biomaterials have been used for the engineering of genitourinary tissues: natu- rally derived materials, such as collagen and alginate, acellular tissue matrices, such as bladder submucosa and smallintestinal submucosa (SIS), and synthetic polymers, such as polyglycolic acid (PGA), polylactic acid, and poly(lactic-coglycolic acid). Although synthetic polymers can be produced reproducibly on a large scale with controlled properties of strength, degradation rate, and microstructure, naturally derived materials and acellular tissue matrices have the potential advantage of biologic recognition, which can lessen host versus graft reactions.

\section{TISSUE ENGINEERING OF SPECIFIC UROLOGIC AND GENITAL STRUCTURES}

\section{Urethra}

Various strategies have been proposed over the years for the regeneration of urethral tissue. Woven meshes of PGA (Dexon) have been used to reconstruct urethras in dogs (18). Also, PGA has been used as a cell transplantation vehicle to engineer tubular urothelium in vivo (1). SIS without cells was used as an onlay patch graft for urethroplasty in rabbits (19). Finally, a homologous graft of acellular urethral matrix was also used in a rabbit model (20).

Bladder-derived acellular collagen matrix has proven to be a suitable graft for repair of urethral defects in rabbits. In the rabbit model, the neourethras created with these matrices demonstrated a normal urothelial luminal lining and organized muscle bundles shortly after repair $(19,20)$. These results were confirmed clinically in a series of patients with a history of failed hypospadias reconstruction, wherein the urethral defects were repaired with human bladder acellular collagen matrices (Fig. 1) (21,22). One of the advantages of this material over nongenital tissue grafts currently used for urethroplasty (e.g., buccal mucosa) is that the material is "off the shelf." This eliminates the necessity of additional surgical procedures for graft harvesting, which may decrease operative time, as well as the potential morbidity due to the harvest procedure.

The above techniques, using nonseeded acellular matrices, were successfully applied experimentally and clinically for
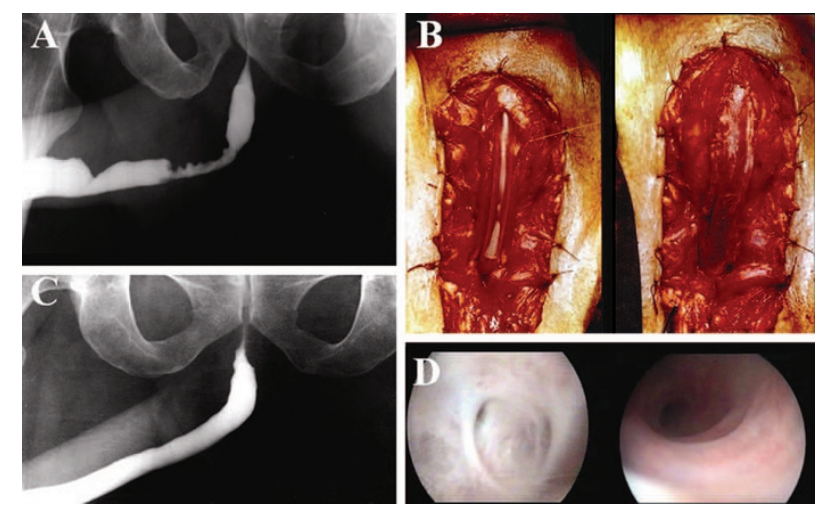

Figure 1. Tissue-engineering of the urethra using a collagen matrix. $(A)$ Representative case of a patient with a bulbar stricture. (B) urethral Repair. Strictured tissue is excised, preserving the urethral plate on the left side, and matrix is anastomosed to the urethral plate in an onlay fashion on the right. (C) Urethrogram 6 mo after repair. (D) Cystoscopic view of urethra before surgery on the left side and 4 mo after repair on the right side. 
onlay urethral repairs. However, when tubularized urethral repairs were attempted experimentally, adequate urethral tissue regeneration was not achieved, and complications ensued, such as graft contracture and stricture formation (23). Tubularized collagen matrices seeded with cells have performed better in animal studies. In a rabbit model, entire urethral segments were resected and urethroplasties were performed with tubularized collagen matrices either seeded with autologous cells or without cells. The tubularized collagen matrices seeded with autologous cells formed new tissue which was histologically similar to native urethral tissue (24). The tubularized collagen matrices without cells lead to poor tissue development, fibrosis, and stricture formation.

\section{Bladder}

Currently, gastrointestinal segments are commonly used for bladder replacement or repair. However, gastrointestinal tissues are designed to absorb solutes that urinary tissue excretes, and due to this difference in function, multiple complications may ensue, such as infection, metabolic disturbances, urolithiasis, perforation, increased mucus production, and malignancy (25-27). Because of the problems encountered with the use of gastrointestinal segments, numerous investigators have attempted alternative reconstructive procedures for bladder replacement or repair. The use of tissue expansion, seromuscular grafts, matrices for tissue regeneration, and tissue engineering with cell transplantation have been investigated.

Tissue expansion for bladder augmentation. A system of progressive dilation for ureters and bladders has been proposed as a method of bladder augmentation but has not yet been attempted clinically. Augmentation cystoplasty performed with dilated ureteral segments in animals has resulted in an increased bladder capacity ranging from $190 \%$ to $380 \%$ $(28,29)$. A system for the progressive expansion of native bladder tissue has also been used for augmenting bladder volumes in animals. Within $30 \mathrm{~d}$ after progressive dilation, the neoreservoir volume was expanded at least 10-fold. Urodynamic studies showed normal compliance in all animals and microscopic examination of the expanded neoreservoir tissue showed a normal histology. A series of immunocytochemical studies demonstrated that the dilated bladder tissue maintained normal phenotypic characteristics (29).

Seromuscular grafts and deepithelialized bowel segments. Seromuscular grafts and deepithelialized bowel segments, either alone or over a native urothelium, have also been attempted (30-35). Keeping the urothelium intact avoids the complications associated with use of bowel in continuity with the urinary tract $(31,32)$. An example of this strategy is the combination of the techniques of autoaugmentation with those of enterocystoplasty. An autoaugmentation is performed and the diverticulum is covered with a demucosalized gastric or intestinal segment.

Matrices for bladder regeneration. Nonseeded allogeneic acellular matrices have served as scaffolds for the ingrowth of host bladder wall components. The matrices are prepared by mechanically and chemically removing all cellular components from bladder tissue (36-39). The matrices serve as vehicles for partial bladder regeneration, and relevant antigenicity is not evident. One example is SIS, a biodegradable, acellular, xenogeneic collagen-based tissue matrix. SIS was first used in the early 1980 s as an acellular matrix for tissue replacement in the vascular field. It has been shown to promote regeneration of a variety of host tissues, including blood vessels and ligaments (40). Animal studies have shown that the nonseeded SIS matrix used for bladder augmentation is able to regenerate in vivo $(41,42)$.

In multiple studies using various materials as nonseeded grafts for cystoplasty, the urothelial layer was able to regenerate normally, but the muscle layer, although present, was not fully developed $(36-38,42)$. Often the grafts contracted to $60 \%-70 \%$ of their original size with little increase in bladder capacity or compliance $(43,44)$. Studies involving acellular matrices that may provide the necessary environment to promote cell migration, growth, and differentiation are being conducted. Recently, bladder regeneration has been shown to be more reliable when the SIS was derived from the distal ileum (41). With continued research in this area, these matrices may have a clinical role in bladder replacement in the future.

Bladder replacement using tissue engineering. Cellseeded allogeneic acellular bladder matrices have been used for bladder augmentation in dogs. A group of experimental dogs underwent a trigone-sparing cystectomy and were randomly assigned to one of three groups. One group underwent closure of the trigone without a reconstructive procedure, another underwent reconstruction with a nonseeded bladdershaped biodegradable scaffold, and the last underwent reconstruction using a bladder-shaped biodegradable scaffold that was seeded with autologous urothelial and smooth muscle cells (45).
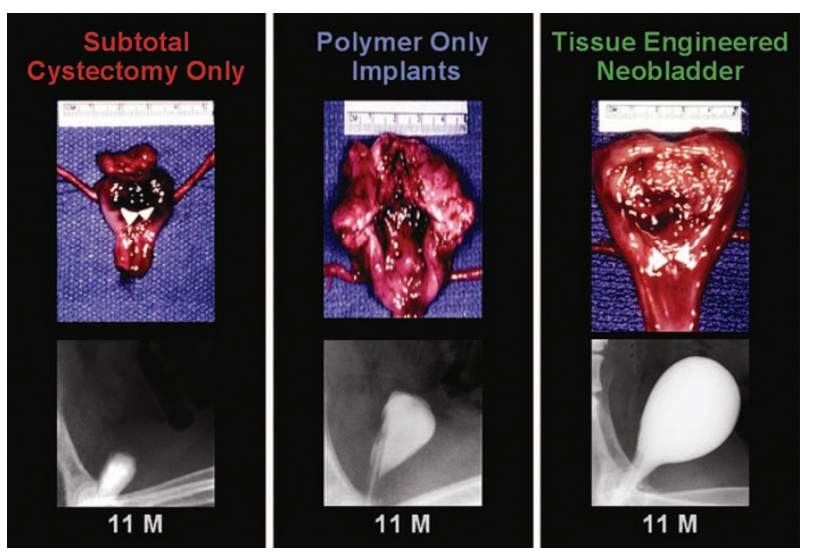

Figure 2. Gross specimens and cystograms at $11 \mathrm{mo}$ of the cystectomy-only, nonseeded controls, and cell-seeded tissue engineered bladder replacements in dogs. The cystectomy-only bladder had a capacity of $22 \%$ of the preoperative value and a decrease in bladder compliance to $10 \%$ of the preoperative value. The nonseeded controls showed significant scarring with a capacity of $46 \%$ of the preoperative value and a decrease in bladder compliance to $42 \%$ of the preoperative value. An average bladder capacity of $95 \%$ of the original precystectomy volume was achieved in the cell-seeded tissue engineered bladder replacements and the compliance showed almost no difference from preoperative values that were measured when the native bladder was present (106\%). 
The cystectomy-only and nonseeded controls maintained average capacities of $22 \%$ and $46 \%$ of preoperative values, respectively. However, an average bladder capacity of $95 \%$ of the original precystectomy volume was achieved in the cellseeded tissue engineered bladder replacements (Fig. 2). The subtotal cystectomy reservoirs that were not reconstructed and the polymer-only reconstructed bladders showed a marked decrease in bladder compliance (10\% and $42 \%$ total compliance, respectively). The compliance of the cell-seeded tissueengineered bladders was almost no different from preoperative values $(106 \%)$. Histologically, the nonseeded scaffold bladders presented a pattern of normal urothelial cells with a thickened fibrotic submucosa and a thin layer of muscle fibers. The retrieved tissue-engineered bladders showed a normal cellular organization, consisting of a trilayer of urothelium, submucosa, and muscle (45).

A clinical experience involving engineered bladder tissue for cystoplasty reconstruction was conducted starting in 1999. A small pilot study of seven patients was reported, using a collagen scaffold seeded with cells either with or without omentum coverage, or a combined PGA-collagen scaffold seeded with cells and omental coverage (see Fig. 3). The patients reconstructed with the engineered bladder tissue created with the PGA-collagen cell-seeded scaffolds showed increased compliance, decreased end-filling pressures, increased capacities and longer dry periods (5). Although the experience is promising in terms of showing that engineered tissues can be implanted safely, it is just a start in terms of accomplishing the goal of engineering fully functional bladders. Further experimental and clinical work is being conducted.

\section{Kidney}

The kidney is the most challenging organ in the genitourinary system to reconstruct because of its extremely complex structure and function. Concepts for a bioartificial kidney are currently being explored. Some investigators are pursuing the replacement of isolated kidney function parameters using extracorporeal units, whereas others are aiming to replace total renal function with tissue-engineered bioartificial renal structures.

Ex vivo functioning renal units. Dialysis is currently the most common form of renal replacement therapy. However, the relatively high morbidity and mortality resulting from this process have spurred investigators to seek alternative solu-

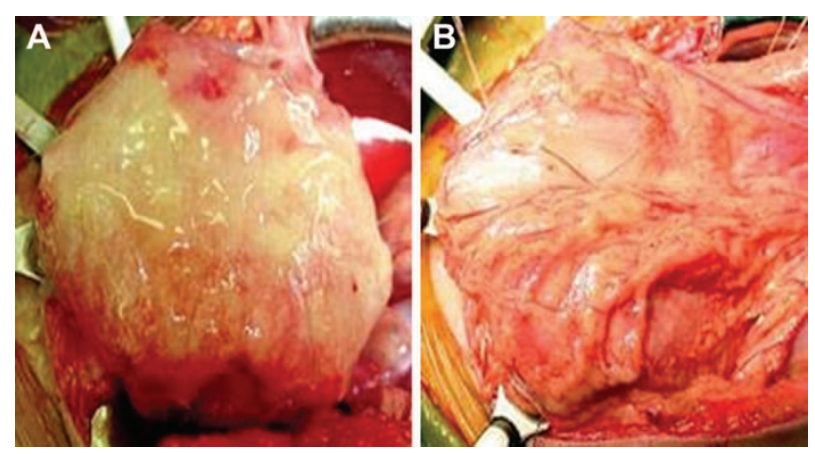

Figure 3. Construction of an engineered human bladder. (A) The engineered bladder anastomosed to native bladder tissue with running 4-0 polyglycolic sutures. $(B)$ Implanted bladder covered with fibrin glue and omentum. tions. In an attempt to assess the viability and physiologic functionality of a cell-seeded device to replace the filtration, transport, metabolic, and endocrinologic functions of the kidney, a synthetic hemofiltration device and a device which contained tissue-engineered porcine renal tubules were incorporated into an extracorporeal perfusion circuit, and this was introduced into acutely uremic dogs. Levels of potassium and blood urea nitrogen were controlled during treatment with the device. The fractional reabsorption of sodium and water was possible. Active transport of potassium, bicarbonate, and glucose, and a gradual ability to excrete ammonia was observed. These results demonstrated the feasibility of an extracorporeal assist device that is reinforced by the use of proximal tubular cells (46).

Using similar techniques, the development of a tissueengineered bioartificial kidney consisting of a conventional hemofiltration cartridge in series with a renal tubule assist device containing human renal proximal tubule cells was used in patients with acute renal failure in the intensive care unit. The initial clinical experience with this bioartificial kidney suggests that renal tubule cell therapy may provide a dynamic and individualized treatment program as assessed by acute physiologic and biochemical indices (47).

Creation of functional renal structures in vivo. Another approach to improve renal function involves the augmentation of renal tissue with kidney cells expanded in vitro and used for subsequent autologous transplantation. Most recently, an attempt was made to reconstitute renal epithelial cells for the generation of functional nephron units. Renal cells were harvested and expanded in culture. The cells were seeded onto a tubular device constructed from a polycarbonate membrane, which was connected at one end to a Silastic catheter that terminated in a reservoir. The device was implanted in athymic mice. Histologic examination of the implanted devices over time revealed extensive vascularization with formation of glomeruli and highly organized tubule-like structures. Immunocytochemical staining confirmed the renal phenotype. Additionally, yellow fluid was collected from inside the implant, and its creatinine and uric acid concentrations were consistent with the makeup of dilute urine. Further studies have shown the formation of renal structures in cows using nuclear transfer techniques (Fig. 4) (48). The expansion of this system to larger, three-dimensional structures is the next challenge awaiting researchers in the urogenital tissue-engineering field.

\section{Genital Tissues}

Reconstruction of corporal smooth muscle. One of the major components of the phallus is corporal smooth muscle. The creation of autologous functional and structural corporal tissue de novo would be beneficial in cases of congenital abnormality of the genitals and in other situations where reconstruction is functionally and esthetically necessary. To look at the functional parameters of engineered corpora, acellular corporal collagen matrices were obtained from donor rabbit penile tissue, and autologous corpus cavernosal smooth muscle and endothelial cells were harvested, expanded, and seeded on the matrices. The entire rabbit corpora was removed 


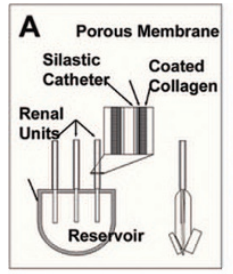

D

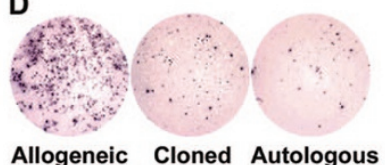

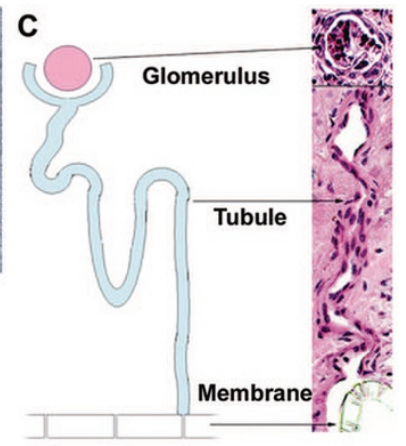

igure 4. Combining therapeutic cloning and tissue engineering to produce kidney tissue. (A) Illustration of the tissue-engineered renal unit. (B) Renal unit seeded with cloned cells, 3 mo after implantation, showing the accumulation of urine-like fluid. (C) There was a clear unidirectional continuity between the mature glomeruli, their tubules, and the polycarbonate membrane. $(D)$ Elispot analyses of the frequencies of $\mathrm{T}$ cells that secrete IFNgamma after primary and secondary stimulation with allogeneic renal cells, cloned renal cells, or nuclear donor fibroblasts.

and replaced with the engineered structures. The experimental corporal bodies demonstrated intact structural integrity by cavernosography and showed similar intracorporal pressures by cavernosometry when compared with the normal controls. Rabbits that received scaffolds without cells failed to achieve normal erectile function throughout the study period. However, mating activity in the animals with the cell-seeded corpora appeared normal by 1 mo after implantation. The presence of sperm was confirmed during mating, and was present in all rabbits with the engineered corpora. The female rabbits that mated with the animals implanted with engineered corpora conceived and delivered healthy pups. Animals implanted with the matrix alone were unable to demonstrate normal mating activity and failed to ejaculate into the vagina $(49,50)$.

Engineered penile prostheses. Although silicone is an accepted biomaterial for penile prostheses, biocompatibility is a concern $(51,52)$. Use of a natural prosthesis composed of autologous cells may be advantageous. In a recent study, the feasibility of applying engineered cartilage rods in situ was investigated (53). Autologous chondrocytes were harvested from rabbit ear and expanded in culture. The cells were seeded onto biodegradable poly-L-lactic acid-coated polyglycolic acid polymer rods and then implanted into the corporal spaces of rabbits. Examination at retrieval showed the presence of wellformed, milky-white cartilage structures within the corpora at $1 \mathrm{mo}$ and the polymer scaffolding had degraded by 2 mo. There was no evidence of erosion or infection in any of the implantation sites. Subsequent studies were performed to assess the long-term functionality of the cartilage penile rods in vivo. To date, the animals have done well and can copulate and impregnate their female partners without problems.

Female genital tissues. Congenital malformations of the uterus may have profound implications clinically. Patients with cloacal exstrophy and intersex disorders may not have sufficient uterine tissue present for future reproduction. We investigated the possibility of engineering functional uterine tissue using autologous cells. Autologous rabbit uterine smooth muscle and epithelial cells were harvested and expanded in culture. These cells were seeded onto preconfigured uterine-shaped biodegradable polymer scaffolds, and these were used for subtotal uterine tissue replacement in the corresponding autologous animals. Upon retrieval, 6 mo after implantation, histologic, immunocytochemical, and Western blot analyses confirmed the presence of normal uterine tissue components. Biomechanical analyses and organ bath studies showed that the functional characteristics of these tissues were similar to those of normal uterine tissue. Breeding studies using these engineered uteri are currently being performed.

Similarly, several pathologic conditions, including congenital malformations and malignancy, can adversely affect normal vaginal development or anatomy. To investigate tissueengineering methods of generating vaginal tissue for use in these situations, vaginal epithelial and smooth muscle cells of female rabbits were harvested, grown, and expanded in culture. These cells were seeded onto biodegradable polymer scaffolds, and the cell-seeded constructs were then implanted into nude mice for up to $6 \mathrm{wk}$. Immunocytochemical, histologic, and Western blot analyses confirmed the presence of vaginal tissue phenotypes. Electrical field stimulation studies in the tissue-engineered constructs showed similar functional properties to those of normal vaginal tissue. When these constructs were used for autologous total vaginal replacement, patent vaginal structures were noted in the tissue-engineered specimens, whereas the noncell-seeded structures were noted to be stenotic (54).

\section{Injectable Therapies}

Both urinary incontinence and vesicoureteral reflux are common conditions affecting the pediatric genitourinary system. Currently, injectable bulking agents are one treatment used clinically for these conditions, but biocompatibility of current synthetic bulking agents is a concern. The ideal substance for endoscopic treatment of reflux and incontinence should be injectable, nonantigenic, nonmigratory, volume stable, and safe for human use. Animal studies have shown that chondrocytes (cartilage cells) can be easily harvested and combined with alginate in vitro and the resulting suspension can be easily injected cystoscopically. The elastic cartilage tissue formed because of the injection is able to correct vesicoureteral reflux without any evidence of obstruction. This technology has been applied in humans for the correction of vesicoureteral reflux in children and for urinary incontinence in adults (Fig. 5) $(55,56)$.

Using cell therapy techniques, the use of autologous smooth muscle cells has been explored for both urinary incontinence and vesicoureteral reflux applications. The potential use of injectable, cultured myoblasts for the treatment of stress urinary incontinence has also been investigated $(57,58)$. The use of injectable muscle precursor cells has also been investigated for use in the treatment of urinary incontinence due to irreversible urethral sphincter injury or maldevelopment (59). A clinical trial involving the use of muscle derived stem cells to treat stress urinary incontinence has also been performed with good results. Biopsies of skeletal muscle were obtained and 

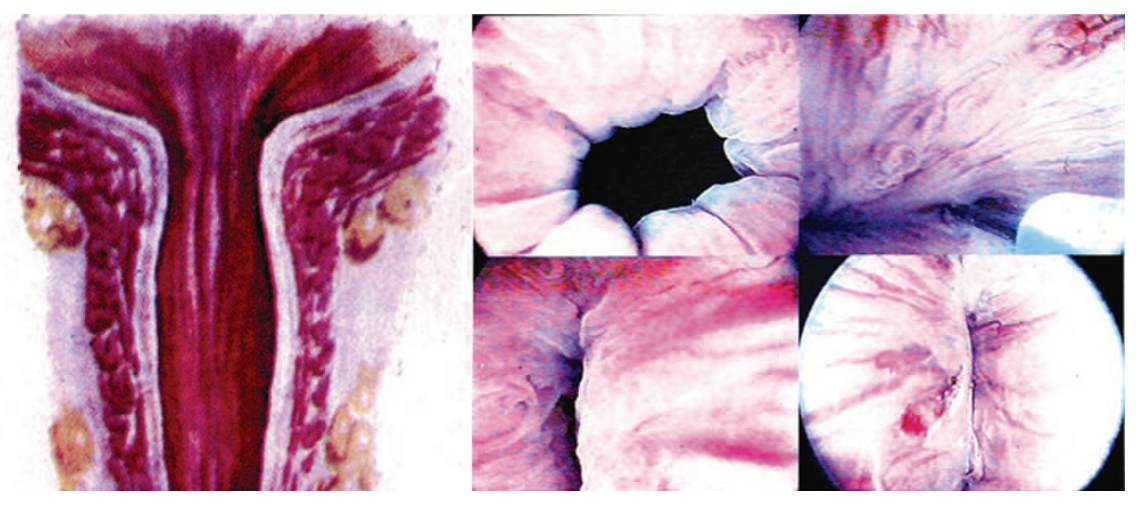

Figure 5. Chondrocytes are harvested and combined with alginate in vitro, and the suspension is injected cystoscopically as a bulking agent to treat urinary incontinence. autologous myoblasts and fibroblasts were cultured. Under ultrasound guidance, myoblasts were injected into the rhabdosphincter and fibroblasts mixed with collagen were injected into the submucosa. One year after injection, the thickness and function of the rhabdosphincter had significantly increased, and all patients were continent (60). These are the first demonstrations of the replacement of both sphincter muscle tissue and its innervation by the injection of muscle precursor cells.

In addition, injectable muscle-based gene therapy and tissue engineering were combined to improve detrusor function in a bladder injury model, and may potentially be a novel treatment option for urinary incontinence (61).

Patients with testicular dysfunction require androgen replacement for somatic development. Conventional treatment for testicular dysfunction consists of periodic intramuscular injections of chemically modified testosterone or application of a transdermal testosterone patch. However, long-term nonpulsatile testosterone therapy is not optimal and can cause multiple problems, including erythropoiesis and bone density changes.

A system was designed wherein Leydig cells were microencapsulated for controlled testosterone replacement. Purified Leydig cells were isolated and encapsulated in an alginatepoly-L-lysine solution. The encapsulated Leydig cells were injected into castrated animals, and serum testosterone was measured serially; the animals were able to maintain testosterone levels in the long term (62). These studies suggest that microencapsulated Leydig cells may be able to replace or supplement testosterone in situations where anorchia or testicular failure is present.

\section{CONCLUSION}

Tissue engineering efforts are currently being undertaken for every type of tissue and organ within the urinary system. Most of the effort expended to engineer genitourinary tissues has occurred within the last decade. Although some tissue engineering applications are beginning to enter clinical practice, many of the new tissue engineering techniques described must be studied further before they can be applied to human disorders. However, recent progress suggests that engineered urologic tissues and cell therapy may have clinical applicability, particularly in reconstruction of this system in children.
Acknowledgment. We thank Dr. Jennifer Olson for editorial assistance with this manuscript.

\section{REFERENCES}

1. Atala A, Vacanti JP, Peters CA, Mandell J, Retik AB, Freeman MR 1992 Formation of urothelial structures in vivo from dissociated cells attached to biodegradable polymer scaffolds in vitro. J Urol 148:658-662

2. Atala A, Cima LG, Kim W, Paige KT, Vacanti JP, Retik AB, Vacanti CA 1993 Injectable alginate seeded with chondrocytes as a potential treatment for vesicoureteral reflux. J Urol 150:745-747

3. Atala A, Freeman MR, Vacanti JP, Shepard J, Retik AB 1993 Implantation in vivo and retrieval of artificial structures consisting of rabbit and human urothelium and human bladder muscle. J Urol 150:608-612

4. Atala A, Kim W, Paige KT, Vacanti CA, Retik AB 1994 Endoscopic treatment of vesicoureteral reflux with a chondrocyte-alginate suspension. J Urol 152:641-643; discussion 644

5. Atala A, Bauer SB, Soker S, Yoo JJ, Retik AB 2006 Tissue-engineered autologous bladders for patients needing cystoplasty. [see comment]. Lancet 367:1241-1246

6. Atala A 2003 Tissue engineering, stem cells, and cloning for the regeneration of urologic organs. Clin Plast Surg 30:649-667

7. Lin HK, Cowan R, Moore P, Zhang Y, Yang Q, Peterson JA Jr, Tomasek JJ, Kropp BP, Cheng EY 2004 Characterization of neuropathic bladder smooth muscle cells in culture. J Urol 171:1348-1352

8. Lai JY, Yoon CY, Yoo JJ, Wulf T, Atala A 2002 Phenotypic and functional characterization of in vivo tissue engineered smooth muscle from normal and pathological bladders. J Urol 168:1853-1857; discussion 1858

9. Brivanlou AH, Gage FH, Jaenisch R, Jessell T, Melton D, Rossant J 2003 Stem cells. Setting standards for human embryonic stem cells. [see comment]. Science 300:913916

10. Thomson JA, Itskovitz-Eldor J, Shapiro SS, Waknitz MA, Swiergiel JJ, Marshall VS, Jones JM 1998 Embryonic stem cell lines derived from human blastocysts. [see comment]. Science 282:1145-1147 [Erratum appears in Science 4;282(5395):1827]

11. De Coppi P, Bartsch G Jr, Siddiqui MM, Xu T, Santos CC, Perin L, Mostoslavsky G, Serre AC, Snyder EY, Yoo JJ, Furth ME, Soker S, Atala A 2007 Isolation of amniotic stem cell lines with potential for therapy. [see comment]. Nat Biotechnol 25:100-106

12. De Coppi P, Callegari A, Chiavegato A, Gasparotto L, Piccoli M, Taiani J, Pozzobon M, Boldrin L, Okabe M, Cozzi E, Atala A, Gamba P, Sartore S 2007 Amniotic fluid and bone marrow derived mesenchymal stem cells can be converted to smooth muscle cells in the cryo-injured rat bladder and prevent compensatory hypertrophy of surviving smooth muscle cells. J Urol 177:369-376

13. Hochedlinger K, Rideout WM, Kyba M, Daley GQ, Blelloch R, Jaenisch R 2004 Nuclear transplantation, embryonic stem cells and the potential for cell therapy. Hematol J 5:S114-S117

14. Kim BS, Baez CE, Atala A 2000 Biomaterials for tissue engineering. World J Urol 18:2-9

15. Kim BS, Mooney DJ 1998 Development of biocompatible synthetic extracellular matrices for tissue engineering. Trends Biotechnol 16:224-230

16. Ponder KP, Gupta S, Leland F, Darlington G, Finegold M, DeMayo J, Ledley FD, Chowdhury JR, Woo SL 1991 Mouse hepatocytes migrate to liver parenchyma and function indefinitely after intrasplenic transplantation. Proc Natl Acad Sci USA $88: 1217-1221$

17. Brittberg M, Lindahl A, Nilsson A, Ohlsson C, Isaksson O, Peterson L 1994 Treatment of deep cartilage defects in the knee with autologous chondrocyte transplantation. [see comment]. N Engl J Med 331:889-895

18. Olsen L, Bowald S, Busch C, Carlsten J, Eriksson I 1992 Urethral reconstruction with a new synthetic absorbable device. An experimental study. Scand J Urol Nephrol 26:323-326

19. Kropp BP, Ludlow JK, Spicer D, Rippy MK, Badylak SF, Adams MC, Keating MA, Rink RC, Birhle R, Thor KB 1998 Rabbit urethral regeneration using small intestinal submucosa onlay grafts. Urology 52:138-142 
20. Sievert KD, Bakircioglu ME, Nunes L, Tu R, Dahiya R, Tanagho EA 2000 Homologous acellular matrix graft for urethral reconstruction in the rabbit: histological and functional evaluation. J Urol 163:1958-1965

21. Atala A, Guzman L, Retik AB 1999 A novel inert collagen matrix for hypospadias repair. J Urol 162:1148-1151

22. Chen F, Yoo JJ, Atala A 1999 Acellular collagen matrix as a possible "off the shelf' biomaterial for urethral repair. Urology 54:407-410

23. le Roux PJ 2005 Endoscopic urethroplasty with unseeded small intestinal submucosa collagen matrix grafts: a pilot study. J Urol 173:140-143

24. De Filippo RE, Yoo JJ, Atala A 2002 Urethral replacement using cell seeded tubularized collagen matrices. J Urol 168:1792-1793

25. McDougal WS 1992 Metabolic complications of urinary intestinal diversion. J Urol 147:1199-1208

26. Kaefer M, Hendren WH, Bauer SB, Goldenblatt P, Peters CA, Atala A, Retik AB 1998 Reservoir calculi: a comparison of reservoirs constructed from stomach an other enteric segments. [see comment]. J Urol 160:2187-2190

27. Kaefer M, Tobin MS, Hendren WH, Bauer SB, Peters CA, Atala A, Colodny AH Mandell J, Retik AB 1997 Continent urinary diversion: the Children's Hospital experience. J Urol 157:1394-1399

28. Lailas NG, Cilento B, Atala A 1996 Progressive ureteral dilation for subsequent ureterocystoplasty. J Urol 156:1151-1153

29. Satar N, Yoo JJ, Atala A 1999 Progressive dilation for bladder tissue expansion J Urol 162:829-831

30. Blandy JP 1961 Ileal pouch with transitional epithelium and anal sphincter as a continent urinary reservoir. J Urol 86:749-767

31. Blandy JP 1964 The feasibility of preparing an ideal substitute for the urinary bladder. Ann R Coll Surg Engl 35:287-311

32. Harada N, Yano H, Ohkawa T, Misse T, Kurita T, Nagahara A 1965 New surgical treatment of bladder tumours: mucosal denudation of the bladder. $\mathrm{Br} \mathrm{J} \mathrm{Urol}$ 37:545-547

33. Oesch I 1988 Neourothelium in bladder augmentation. An experimental study in rats. Eur Urol 14:328-329

34. Salle JL, Fraga JC, Lucib A, Lampertz M, Jobim G, Jobim G, Putten A 1990 Seromuscular enterocystoplasty in dogs. J Urol 144:454-456; discussion 460

35. Cheng E, Rento R, Grayhack JT, Oyasu R, McVary KT 1994 Reversed seromuscular flaps in the urinary tract in dogs. J Urol 152:2252-2257

36. Yoo JJ, Meng J, Oberpenning F, Atala A 1998 Bladder augmentation using allogenic bladder submucosa seeded with cells. Urology 51:221-225

37. Probst M, Dahiya R, Carrier S, Tanagho EA 1997 Reproduction of functional smooth muscle tissue and partial bladder replacement. Br J Urol 79:505-515

38. Sutherland RS, Baskin LS, Hayward SW, Cunha GR 1996 Regeneration of bladder urothelium, smooth muscle, blood vessels and nerves into an acellular tissue matrix. J Urol 156:571-577

39. Piechota HJ, Dahms SE, Nunes LS, Dahiya R, Lue TF, Tanagho EA 1998 In vitro functional properties of the rat bladder regenerated by the bladder acellular matrix graft. J Urol 159:1717-1724

40. Badylak SF, Lantz GC, Coffey A, Geddes LA 1989 Small intestinal submucosa as a large diameter vascular graft in the dog. J Surg Res 47:74-80

41. Kropp BP, Cheng EY, Lin HK, Zhang Y 2004 Reliable and reproducible bladde regeneration using unseeded distal small intestinal submucosa. J Urol 172:1710 1713

42. Kropp BP, Rippy MK, Badylak SF, Adams MC, Keating MA, Rink RC, Thor KB 1996 Regenerative urinary bladder augmentation using small intestinal submucosa: urodynamic and histopathologic assessment in long-term canine bladder augmentations. J Urol 155:2098-2104
43. Portis AJ, Elbahnasy AM, Shalhav AL, Brewer A, Humphrey P, McDougall EM, Clayman RV 2000 Laparoscopic augmentation cystoplasty with different biodegradable grafts in an animal model. J Urol 164:1405-1411

44. Landman J, Olweny E, Sundaram CP, Andreoni C, Collyer WC, Rehman J, Jerde TJ Lin HK, Lee DI, Nunlist EH, Humphrey PA, Nakada SY, Clayman RV 2004 Laparoscopic mid sagittal hemicystectomy and bladder reconstruction with smal intestinal submucosa and reimplantation of ureter into small intestinal submucosa: 1-year followup. J Urol 171:2450-2455

45. Oberpenning F, Meng J, Yoo JJ, Atala A 1999 De novo reconstitution of a functional mammalian urinary bladder by tissue engineering. [see comment]. Nat Biotechnol 17:149-155

46. Humes HD, Buffington DA, MacKay SM, Funke AJ, Weitzel WF 1999 Replacement of renal function in uremic animals with a tissue-engineered kidney. [see comment] Nat Biotechnol 17:451-455

47. Humes HD, Weitzel WF, Bartlett RH, Swaniker FC, Paganini EP 2003 Renal cell therapy is associated with dynamic and individualized responses in patients with acute renal failure. Blood Purif 21:64-71

48. Lanza RP, Chung HY, Yoo JJ, Wettstein PJ, Blackwell C, Borson N, Hofmeister E, Schuch G, Soker S, Moraes CT, West MD, Atala A 2002 Generation of histocompatible tissues using nuclear transplantation. [see comment]. Nat Biotechnol 20:689696

49. Yoo JJ, Park HJ, Atala A 2000 Tissue-engineering applications for phallic reconstruction. World J Urol 18:62-66

50. Yoo JJ, Atala A 2002 Tissue engineering of genitourinary organs. Ernst Schering Res Found Workshop:105-127

51. Nukui F, Okamoto S, Nagata M, Kurokawa J, Fukui J 1997 Complications an reimplantation of penile implants. Int J Urol 4:52-54

52. Thomalla JV, Thompson ST, Rowland RG, Mulcahy JJ 1987 Infectious complications of penile prosthetic implants. J Urol 138:65-67

53. Yoo JJ, Park HJ, Lee I, Atala A 1999 Autologous engineered cartilage rods for penile reconstruction. J Urol 162:1119-1121

54. De Filippo RE, Yoo JJ, Atala A 2003 Engineering of vaginal tissue in vivo. Tissue Eng 9:301-306

55. Diamond DA, Caldamone AA 1999 Endoscopic correction of vesicoureteral reflux in children using autologous chondrocytes: preliminary results. J Urol 162:11851188

56. Bent AE, Tutrone RT, McLennan MT, Lloyd LK, Kennelly MJ, Badlani G 2001 Treatment of intrinsic sphincter deficiency using autologous ear chondrocytes as a bulking agent. Neurourol Urodyn 20:157-165

57. Yokoyama T, Huard J, Chancellor MB 2000 Myoblast therapy for stress urinary incontinence and bladder dysfunction. World J Urol 18:56-61

58. Chancellor MB, Yokoyama T, Tirney S, Mattes CE, Ozawa H, Yoshimura N, de Groat WC, Huard J 2000 Preliminary results of myoblast injection into the urethra and bladder wall: a possible method for the treatment of stress urinary incontinence and impaired detrusor contractility. Neurourol Urodyn 19:279-287

59. Yiou R, Yoo JJ, Atala A 2003 Restoration of functional motor units in a rat model of sphincter injury by muscle precursor cell autografts. Transplantation 76:10531060

60. Strasser H, Berjukow S, Marksteiner R, Margreiter E, Hering S, Bartsch G, Hering S 2004 Stem cell therapy for urinary stress incontinence. Exp Gerontol 39:12591265

61. Huard J, Yokoyama T, Pruchnic R, Qu Z, Li Y, Lee JY, Somogyi GT, de Groat WC Chancellor MB 2002 Muscle-derived cell-mediated ex vivo gene therapy for urological dysfunction. Gene Ther 9:1617-1626

62. Machluf M, Orsola A, Boorjian S, Kershen R, Atala A 2003 Microencapsulation of Leydig cells: a system for testosterone supplementation. Endocrinology 144:49754979 